\title{
NIH: Imanishi-Kari guilty
}

\section{Washington}

FIVE years after charges were first made, one of the longest, most painful misconduct cases in US science history may have reached its end. In a 280-page draft report, the US National Institutes of Health (NIH) have found that Tufts University biologist Thereza Imanishi-Kari fabricated key data in a 1986 Cell paper of which Nobel laureate David Baltimore, now the president of Rockefeller University, was also an author.

The report, which was leaked to journalists last week, reverses the conclusions of a previous NIH investigation and earlier inquiries at Tufts University and the Massachusetts Institute of Technology, where Imanishi-Kari had done the original work. It finds that data from two critical experiments described in the paper were "fabricated" and that Imanishi-Kari "repeatedly presented false and misleading information to the NIH" and other investigative panels to hide that fact.

Baltimore last week retracted the Cell paper and issued a statement saying that the $\mathrm{NIH}$ report "raises very serious question about the veracity of the serological data in the paper". And he added "It is up to Dr Imanishi-Kari to resolve them".

The principal finding of the paper - that transplanted genes influence a mouse's own genes - was based on data supplied by Imanishi-Kari that purportedly described experiments on transgenic mice. "It remains unclear if these experiments were actually done," the OSI report finds. "But if they were, the resulting data must have been deemed unreliable or otherwise unsatisfactory, since an attempt was made to substitute other data for them."

Imanishi-Kari, Baltimore and Margot O'Toole, the whistleblower in the case, have 30 days to respond to the draft report before it becomes final. Should the conclusions remain unchanged, the NIH Office of Scientific Integrity (OSI), which investigated the case, will recommend sanctions to NIH's parent agency, the Department of Health and Human Services (HHS). If OSI recommends that Imanishi-Kari be denied further federal research support - a typical response - HHS would begin a formal debarment proceeding.

In a worst-case scenario, such a procedure could take another two years while the case is heard again, something OSI deputy director Suzanne Hadley describes as "daunting to consider, but not impossible".

Although the report reviews the laboratory notebooks in exhaustive detail, it does not appear to make a completely airtight case for Imanishi-Kari's guilt. Secret Service analysis of certain handwritten notebook entries purportedly copied from gamma-counter readings of Imanishi-Kari's experiments showed a statistically improbable favouring of the numbers $1,3,7$ or 8 in the 'tens' digit.

The Secret Service determined that the odds of such 'spikiness' naturally occurring is less than 1 in 100,000 .

But a dissenting opinion by Hugh McDevitt and Ursula Storb, two of OSI's fivemember independent review committee, raises questions about the statistical analysis. Because such analysis is new to the investigation of scientific fraud and little work has been carried out on number distribution in scientific data, the two committee members felt that "we can only conclude that [the analysis] is interesting, but not compelling, and certainly not adequate grounds for an allegation or conclusion of fabrication".

They did, however, find the Secret Service forensic analysis of certain gamma-counter tapes in Imanishi-Kari's notebooks more convincing. Chromatographic comparison of the inks and print quality of the tapes against similar data from other researchers in the same MIT laboratory indicated that the tapes purportedly printed in 1985 experiments were actually made as much as three years earlier (see Nature 347, 317; 507, 1990). Even for these sceptical members of the panel, that analysis "makes it seem likely that the data on these pages are not the result of experiments performed at or near the time stated".

\section{Six years of intrigue}

May 1985: Thereza Imanishi-Kari carries out transgenic mouse experiments at MIT. April 1986: Original paper based on the mouse data is published in Cell by ImanishiKari, David Baltimore and others.

May 1986: Laboratory postdoctoral fellow Margot O'Toole discovers an Imanishi-Kari notebook containing 17 pages that suggested to her that some of the key experiments in the Cell paper had never been done; Tufts University, which is preparing to hire Imanishi-Kari, convenes an ad hoc committee headed by biologist Henry Wortis to investigate charges.

June 1986: MIT professor Herman Eisen meets O'Toole, Imanishi-Kari and Baltimore to review 0 'Toole's allegations. His memorandum finds possible minor errors, but no fraud.

October 1986: NIH researchers Walter Stewart and Ned Feder examine the 17 notebook pages and inform NIH officials that they suspect misconduct.

May 1987: NIH Office of Extramural Research begins first inquiry; Tufts committee submits report concluding that there was no deliberate falsification or misrepresentation in the Cell paper.

May 1988: Congressional Investigations Subcommittee of Representative John Dingell holds its first hearings, focusing on the response of Tufts and MIT to the O'Toole allegations; Baltimore issues a "Dear Colleague" letter attacking Dingell and asserting that congressional interference "is totally unnecessary".
The dissenting opinion rejects five of the seven OSI conclusions of misconduct, arguing that the findings "are open to several alternative interpretations". But the opinion does not specify what those other interpretations might be, and both McDevitt and Storb declined last week to elaborate on their written statement.

Late last week, OSI sent a letter to parties in the investigation that revealed errors in the report. Tapes that were described in the report as green were actually yellow, OSI admitted. OSI said that the overall results nevertheless "stand as stated".

OSI intends to review also the Tufts and MIT investigations, to determine if they were handled correctly, Hadley says, although the office may not issue a formal report on that point. Congressman John Dingell, chairman of the House of Representatives Energy and Commerce oversight and investigations subcommittee, which has so far held four hearings on the case, intends to hold yet another hearing in late April or May. Peter Stockton, a subcommittee staff member, says the hearing will address the "who-knew-what-when" aspects of the earlier investigations. Baltimore and Imanishi-Kari will be called to testify, among other witnesses, Stockton says.

Brigitte Huber, a member of the Tufts committee that found no evidence of misconduct, says that lack of investigative resources had forced her committee to accept

July 1988: Dingell subpoenas ImanishiKari's laboratory records and turns the notebooks over to Secret Service for analysis. November 1988: Baltimore and ImanishiKari publish a correction in Cell indicating that the original paper contained an "overstatement" of the specificity of BET-1, a key reagent.

January 1989: First NIH investigation ends, finding "significant errors of mis-statement and omission... [but] no evidence of fraud, conscious misrepresentation, or manipulations of data".

April 1989: Based on new evidence from the continuing Dingell investigation and subsequent O'Toole findings, NIH reopens the investigation within the newly created Office of Scientific Integrity.

May 1989: Dingell holds two hearings, at the first of which the Secret Service testifies that 20 per cent of a critical notebook is forensically questionable; on the direction of $\mathrm{NIH}$, Baltimore and Imanishi-Kari publish a second correction in Cell, giving additional data on the specificity of BET-1.

May 1990: Dingell holds fourth hearing. Secret Service investigators present additional forensic data showing that ImanishiKari's notebook records and purported experiments were "not contemporaneous with respect to time". Findings cast doubt on the data in the second Cell correction.

March 1991: Draft report of second NIH investigation reverses previous report, finds "serious scientific misconduct", including data fabrication. 